\title{
THE EFFECT OF THE SIZE OF PARTICLES ON MINERALIZATION OF Oxycaryum cubense (POEPP. \& KUNTH) LYE
}

\author{
BIANCHINI JR., I. ${ }^{1,2}$ and CUNHA-SANTINO, M. B. ${ }^{1}$ \\ ${ }^{1}$ Programa de Pós Graduação em Ecologia e Recursos Naturais, Universidade Federal de São Carlos, \\ Rodovia Washington Luis, Km 235, CEP 13565-905, C. P. 676, São Carlos, SP, Brasil \\ ${ }^{2}$ Departamento de Hidrobiologia, Universidade Federal de São Carlos, Rodovia Washington Luis, Km 235, \\ CEP 13565-905, C. P. 676, São Carlos, SP, Brasil
}

Correspondence to: Irineu Bianchini Júnior, Departamento de Hidrobiologia, Universidade Federal de São Carlos, Rodovia Washington Luis, Km 235, CEP 13565-905, C. P. 676, São Carlos, SP, Brasil, e-mail: mbcunha@cosmo.com.br Received July 7, 2004 - Accepted April 25, 2005 - Distributed May 31, 2006

(With 4 figures)

\begin{abstract}
Assays were carried out to evaluate effects of detritus size on the mineralization of an aquatic macrophyte, the Oxycaryum cubense. Samples of plant and water were collected from an oxbow lake, the Infernão lagoon $\left(21^{\circ} 35^{\prime} \mathrm{S}\right.$ and $\left.47^{\circ} 51^{\prime} \mathrm{W}\right)$ located at Mogi Guaçu river floodplain. The plants were taken to the laboratory, washed under tap water, $\operatorname{dried}\left(50^{\circ} \mathrm{C}\right)$ and fractioned into six groups according to their size, viz. $100,10,1.13$, $0.78,0.61$ and $0.25 \mathrm{~mm}$. Decomposition chambers were prepared by adding $1.0 \mathrm{~g}$ of plant fragments to $4.1 \mathrm{~L}$ of water lagoon. In sequence, the incubations were aerated and the concentrations of dissolved oxygen, the $\mathrm{pH}$, the electric conductivity and the temperature were monitored for 120 days. The occurrence of anaerobic processes was avoided by reoxygenating the solutions. The experimental results were fitted to a first order kinetic model and the consumption of dissolved oxygen from mineralization processes was obtained. The physical process of fragmentation of $O$. cubense detritus is unlikely to promote the consumption of higher quantities of dissolved oxygen in mineralization processes meaning that fragmentation should not interfere in the balance of DO in this aquatic system, however fragmentation processes favored the acidification and increased the liberation of dissolved ions from the Infernão lagoon.
\end{abstract}

Keywords: mineralization, Oxycaryum cubense, aquatic macrophytes, detritus size.

\section{RESUMO}

\section{O Efeito do Tamanho de Partículas na Mineralização de Oxycaryum cubense (Poepp. \& Kunth) Lye}

Ensaios foram realizados para avaliar os efeitos de tamanho dos detritos na mineralização de uma macrófita aquática, a Oxycaryum cubense. Foram coletadas amostras de planta e de água de uma lagoa marginal, a lagoa do Infernão $\left(21^{\circ} 35^{\prime} \mathrm{S}\right.$ e $\left.47^{\circ} 51^{\prime} \mathrm{W}\right)$, localizada na planície de inundação do rio Mogi Guaçu. As plantas foram levadas ao laboratório, lavadas em água corrente, secas $\left(50^{\circ} \mathrm{C}\right)$ e fracionadas em seis grupos de acordo com o tamanho: 100, 10, 1,13, 0,78, 0,61 e 0,25 mm. Foram preparadas câmaras de decomposição adicionando aproximadamente $1,0 \mathrm{~g}$ de fragmentos de planta em 4,1 L de água da lagoa. Na sequiência, as incubações foram aeradas e as concentrações de oxigênio dissolvido, o pH, a condutividade elétrica e a temperatura foram monitorados durante 120 dias. A ocorrência de processos de anaeróbios foi evitada por reoxigenação das soluções. Os resultados experimentais foram ajustados a um modelo cinético de primeira ordem e o consumo de oxigênio dissolvido decorrente da mineralização foi obtido. De maneira geral, o processo físico de fragmentação não tende a envolver maiores quantidades de oxigênio durante a mineralização aeróbia dos detritos, significando que a fragmentação não interfere no balanço de oxigênio dissolvido deste sistema aquático; entretanto favoreceu a acidificação e também a liberação de íons dissolvidos na lagoa do Infernão.

Palavras-chave: mineralização, Oxycaryum cubense, macrófitas aquáticas, tamanho do detrito. 


\section{INTRODUCTION}

A decomposition process is a result from changes of state of a given substrate under the influence of biotic and abiotic factors. One simplest way of monitoring these changes is by measuring mass loss. Degradation resulted from three distinct mechanisms: leaching, catabolism and fragmentation. Leaching is an abiotic process by which soluble material is removed by water from the substrate. Catabolism consists in transforming complex organic matter into compounds with simple, small molecules and takes place through biochemical reactions. Within a given period, catabolism of a substrate may be incomplete (Mackensen \& Bauhus, 1999) in which case the resulting products (organic and inorganic) may enter the metabolism of decomposers, being consequently re-synthesized and incorporated into these organisms. Other products may be incorporated and/or converted into the class of non-cellular organic compounds such as humic substances (Lu et al., 2001). The mass loss owing to catabolic formation of labile substances and soluble organic and inorganic matter will later be leached and incorporated into biomass of microorganisms. In the fragmentation process, the size of particulate detritus is reduced. It differs from catabolism because it has a physical nature and is generally related to feeding activities - ingestion as well as digestion by decomposing agents. However, during digestion fragmentation may be followed by catabolic changes. The residual matter thus generated may be expelled as smaller particles and have a chemical composition different from the original ingested material. Detritus may also be fragmentized in processes not related to digestion; this is the case of abiotic mechanisms (Allan, 1995) such as thunderstorms, mechanical action of wind and turbulence. Hence, fragmentation is not accompanied by chemical composition changes.

In practice, changes in chemical composition of detritus occur when intermediate products are formed (Panhota \& Bianchini Jr., 2003) and also through the synthesis of new structures by decomposing agents and formation of humic compounds. It is difficult to distinguish between these 3 mechanisms since they may occur simultaneously in a resource. Because of the increase in the specific surface area upon fragmentation, the access of enzymes is facilitated thus increasing the probability of dissolution and catabolism of the detritus. Degradation experiments on $O$. cubense, with emphasis on leaching processes, indicated that fragmentation tended to: i) increase the fraction of detritus to be dissolved and to cause a decrease in the leaching rates due to the possible dissolution of refracting structures; ii) favor the rates of formation and the quantity of colored compounds, probably due to the increase of the amount of polyphenols, polysaccharides and amine compounds; iii) increase the amount of liberated electrolytes; and iv) keep the medium acidity (Bianchini Jr. \& Antonio, 2003).

The velocity with which carbon and nutrients are cycled and accumulated in ecosystems depends basically on the budget between immobilization and mineralization processes. Immobilization is referred to as the process by which a given chemical element remains in the organic form or is incorporated into organic matter. In aquatic systems, such a process is usually carried out by phytoplankton and microorganism communities, by the roots of aquatic plants and also through chemical reactions involving humic compounds and adsorption processes. Mineralization occurs when inorganic matter is liberated from the resource during catabolism. Hence, the availability of a given element depends on the net mineralization.

The aim of this work is to describe the effects of physical processes of fragmentation and the effects of fragmentation on mineralization of aquatic macrophyte (Oxycaryum cubense Poepp \& Kunth). The influence of fragmentation on detritus cycling in the Infernão lagoon was also discussed.

\section{MATERIALS AND METHODS}

Adult samples of Oxycaryum cubense (Poepp. \& Kunth) Lye were collected from an oxbow lake, the Infernão lagoon, sited at the Mogi Guaçu river floodplain $\left(21^{\circ} 35^{\prime} \mathrm{S}\right.$ and $\left.47^{\circ} 51^{\prime} \mathrm{W}\right)$ in the Estação Ecológica de Jataí (SP, Brazil). Oxycaryum cubense is an emergent plant found mainly in the littoral zone of lentic systems. This aquatic macrophyte species is popularly known as "capim-de-capivara" and belongs to the Cyperaceae family. The stolons are scaly, rooting at nodes or with long-hanging roots. Stems are slender, triangular and erect and the leaves are elaminate proximally or laminate distally. 
The inflorescence presents from 1 to 13 heads, and is globose to broadly ovoid. The colour of achenes are pale or red-brown and its morphology are ovoid or ellipsoid (Joly, 1977; Hoehne, 1979). This specie is the most abundant in the Infernão lagoon and plays an important role in the cycling of the autochthonous detritus (Nogueira et al., 1996).

After collection, the plants were dried $\left(\approx 50{ }^{\circ} \mathrm{C}\right)$ and triturated; the set of sieves was used to fractionate the plant fragments. This fractionating process generated six groups of particles (Table 1). For each size of detritus, decomposition chambers were prepared by adding $1.0 \mathrm{~g}$ (DW) of plant fragments in $4.0 \mathrm{~L}$ of lagoon water (previously prefiltered through glass wool). In order to maintain the solutions under aerobic conditions, they were oxygenated (with clear air) for $1 \mathrm{~h}$, to keep dissolved $\mathrm{O}_{2}$ near saturation. After oxygenation, the dissolved oxygen (DO) was measured with OD meter (Metrohm Herisau AGCH-9100/E-637). Whenever the DO concentrations were below $2.0 \mathrm{mg} . \mathrm{L}^{-1}$ on sampling day measurements, the solutions were oxygenated again (during $1 \mathrm{~h}$ ) until DO reached the saturation value. A control bottle (blank) containing only lagoon water was also used to measure the DO. The bottles were incubated at room temperature $\left(25.2 \pm 4.8{ }^{\circ} \mathrm{C}\right)$ for 120 days. The concentration of DO and the temperature were periodically measured with an OD meter; the electrical conductivity and $\mathrm{pH}$ were measured with a potentiometer (Micronal CD-2P and Digimed DMPH-2, respectively) and the total amount of electrolytes was estimated using a standard curve prepared with $\mathrm{NaCl}$. After each measuring procedure, the bottles were closed in order to avoid atmospheric oxygen diffusion.

The consumption of oxygen was assumed to be directly related to the oxidation of the organic resource, and this process could be represented by first-order kinetic models (Henze et al., 2001; Cunha-Santino \& Bianchini Jr., 2002). Hence, the variation in DO decay and its DO consumption can be described by Equations 1 and 2, respectively:

$\frac{d[D O]}{d t}=-k_{d} D O$

where: [DO]: the change in oxygen concentration per unit time $\left(\mathrm{mg} . \mathrm{L}^{-1}\right) ; \mathrm{k}_{\mathrm{d}}$ : deoxygenation coefficient $\left(\right.$ day $\left.^{-1}\right)$ and t: time (day).

$\frac{d O C}{d t}=k_{d} D O-k_{r} O C$

where: OC: evolution of DO consumption (mg.L $\left.\mathrm{L}^{-1}\right)$ and $\mathrm{k}_{\mathrm{r}}$ : reaeration coefficient $\left(\right.$ day $\left.^{-1}\right)$, derived from the method of DO determination by stirring the sample when using a probe to take DO measurements.

The effects of particle size of detritus on oxygen consumption were evaluated by a KruskalWallis test.

The temporal variation of total electrolytes (TE) was fitted to a first-order kinetics model similar to the one described by Bianchini Jr. \& Antonio (2003). Hence, the variation in leaching and uptake of TE can be described by Equation 3.

$\frac{d T E}{d t}=k_{1} A_{0}-k_{a} T E$

where: $A_{0}$ : maximum quantity of total electrolytes $\left(\mathrm{mg} \cdot \mathrm{g}^{-1}\right), \mathrm{k}_{\mathrm{l}}$ : leachate coefficient $\left(\right.$ day $\left.^{-1}\right)$ and $\mathrm{k}_{\mathrm{a}}$ : assimilation coefficient $\left(\right.$ day $\left.^{-1}\right)$.

\section{RESULTS AND DISCUSSION}

Results from mineralization in the control chamber are shown in Fig. 1; the oxidation of dissolved organic matter (DOM) led to a continuous increase in the concentration of dissolved electrolytes (Fig. 1a) indicating that mineralization (conversion from organic into

TABLE 1

Selected Particle size.

\begin{tabular}{|c|c|c|}
\hline Group & Size range $(\mathbf{m m})$ & Average size $(\mathbf{m m})$ \\
\hline I & 100 & 100 \\
\hline II & 10 & 10 \\
\hline III & $0.84<\mathrm{x}<1.41$ & 1.13 \\
\hline IV & $0.71<\mathrm{x}<0.84$ & 0.78 \\
\hline V & $0.50<\mathrm{x}<0.71$ & 0.61 \\
\hline VI & $\mathrm{x}<0.50$ & 0.25 \\
\hline \multicolumn{3}{|c|}{}
\end{tabular}

Braz. J. Biol., 66(2B): 641-650, 2006 


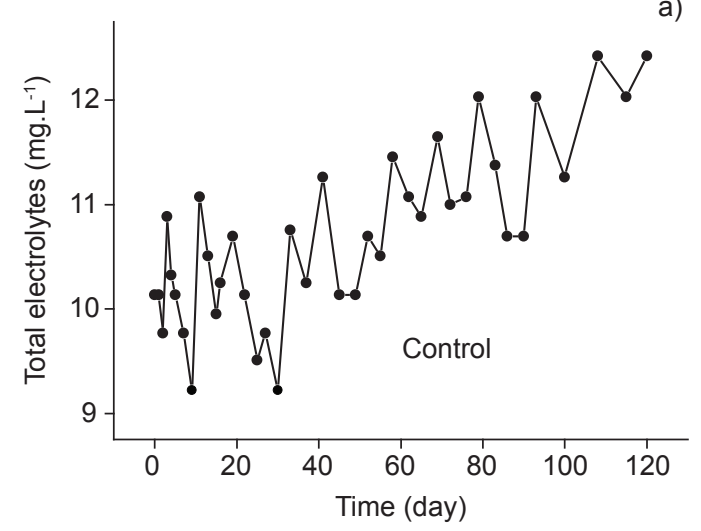

c)

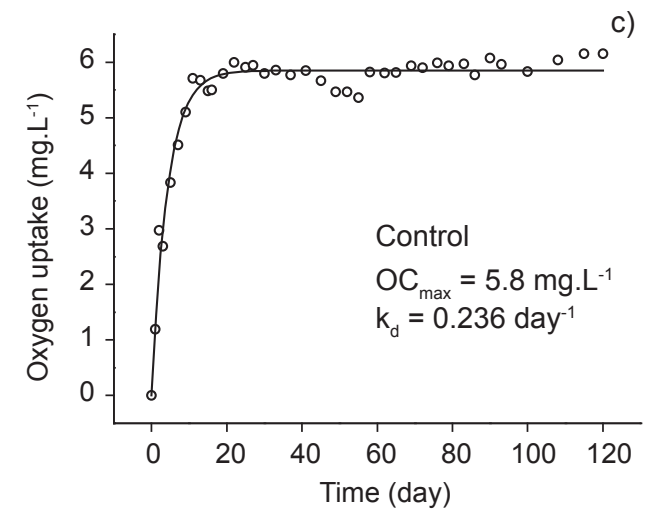

b)

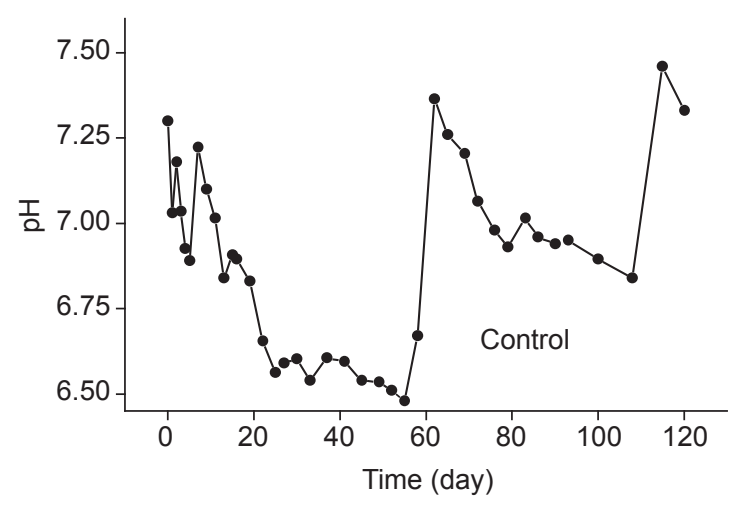

d)

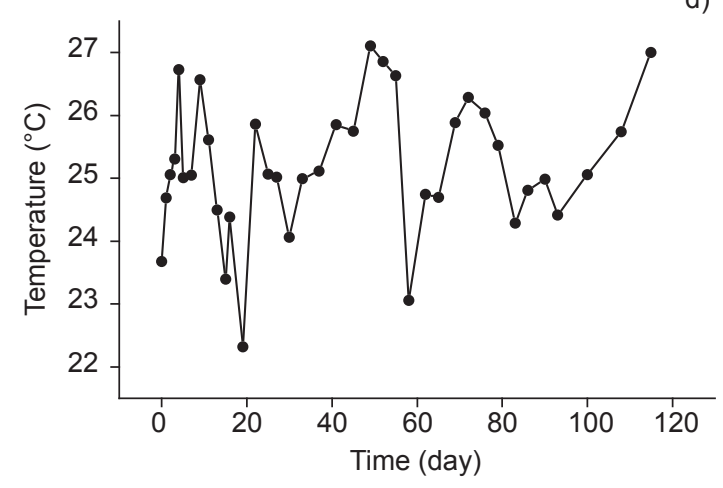

Fig. 1 - Time evolution of: a) total dissolved electrolytes; b) pH; and c) oxygen uptake in the control bottle, during the mineralization of dissolved organic matter from the Lagoa do Infernão (DOM). Temperature variation in the bottles in the experiment is shown in $\mathrm{d}$.

inorganic compounds) gradually predominated over immobilization (e.g. growth of microorganisms). The water $\mathrm{pH}$ also tended to decrease, with the DO consumption mainly until the $19^{\text {th }}$ day of experiments (Figs. 1b and 1c). Experiments were carried out at mean room temperature of $25.2^{\circ} \mathrm{C}$ (maximum: $27.1{ }^{\circ} \mathrm{C}$; minimum: $22.3{ }^{\circ} \mathrm{C}$; Fig. $1 \mathrm{~d}$ ). The temporal evolution of the consumption of DO obeys first order kinetics (Equations 1 and 2), similar to those obtained in long term BOD experiments (Bitar \& Bianchini Jr., 2002). By matching the experimental data to Equations 1 and 2, one can infer that the oxidation of DOM from the Infernão lagoon generated a background oxygen consumption $\left(\mathrm{OC}_{\max }\right.$ ) of $5.8 \mathrm{mg} . \mathrm{L}^{-1}$ (halftime $\left(\mathrm{t}_{1 / 2}\right)=2.9$ days $)$ when the experiments were being done.

The temporal changes of $\mathrm{pH}$ during mineralization of the various sizes of particle from
O. cubense are shown in Fig. 2. An overall decrease in $\mathrm{pH}$ values when the detritus was added was observed. This decrease is caused by the formation of nitrate (via nitrification) and carbonic acid (via respiration) from the catabolic (Cunha-Santino \& Bianchini Jr., 2002) and also by the liberation of organic acids from leaching (Gupta et al., 1996; Mun et al., 2001). Overall, the $\mathrm{pH}$ values from the chambers presented low variation (from 6.4 to 7.1), even though for the largest particles (Group IV, V and VI) a trend towards a lower $\mathrm{pH}$ was observed. The changes on the temporal variation of $\mathrm{pH}$ were mainly caused by periodic acidification due to buffering and alcalinization of the medium. Alcalinization is associated with two factors: i) the reaeration of the bottle due to experimental procedures (Cunha-Santino \& Bianchini Jr., 2003); these arguments are also applied to the control chamber; indeed, the peaks in the curve for the 

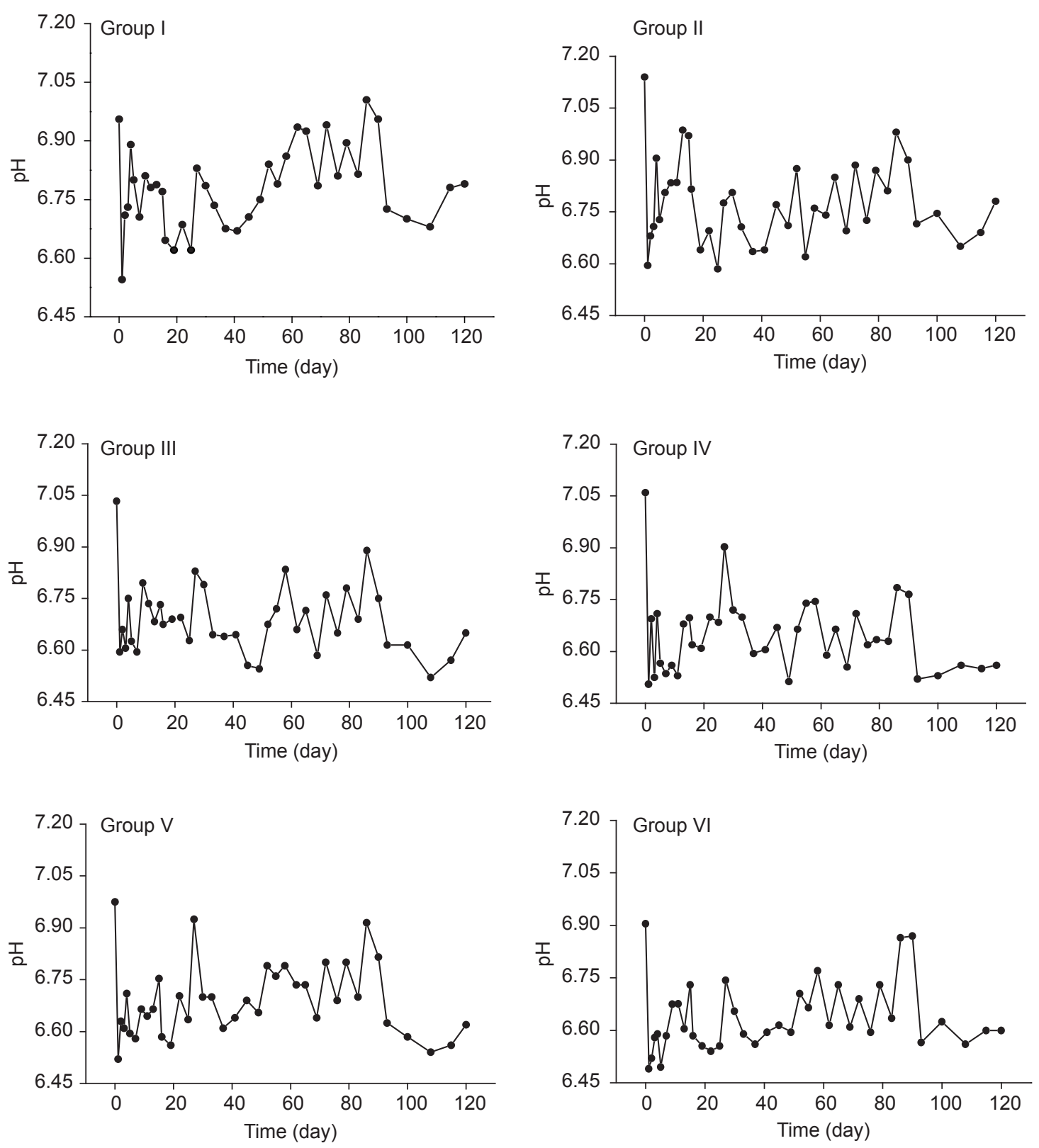

Fig. 2 - Changes of pH during the decay of Oxycaryum cubense with different particle size.

control bottle (Fig. 1b) correspond to the dates when oxygenation occurred; and ii) the formation of carbonates and the action of humic compounds formed during degradation (Bianchini Jr. \& Toledo, 1988; Cunha-Santino \& Bianchini Jr., 2004).

When effects from mineralization of DOM (control bottle) are discounted, it is possible to observe that at the beginning of the mineralization process for $O$. cubense, the inorganic compounds tended to be considerably leached from the detritus (Fig. 3). Therefore, their dissolution coefficients were higher (variation from 0.17 for Group VI to 3.66 day $^{-1}$ for Group I) than the assimilation (immobilization) coefficients (variation from 0.0021 for Group IV to 0.0050 day $^{-1}$ for Group VI). After the second week, dissolution practically ceased and 

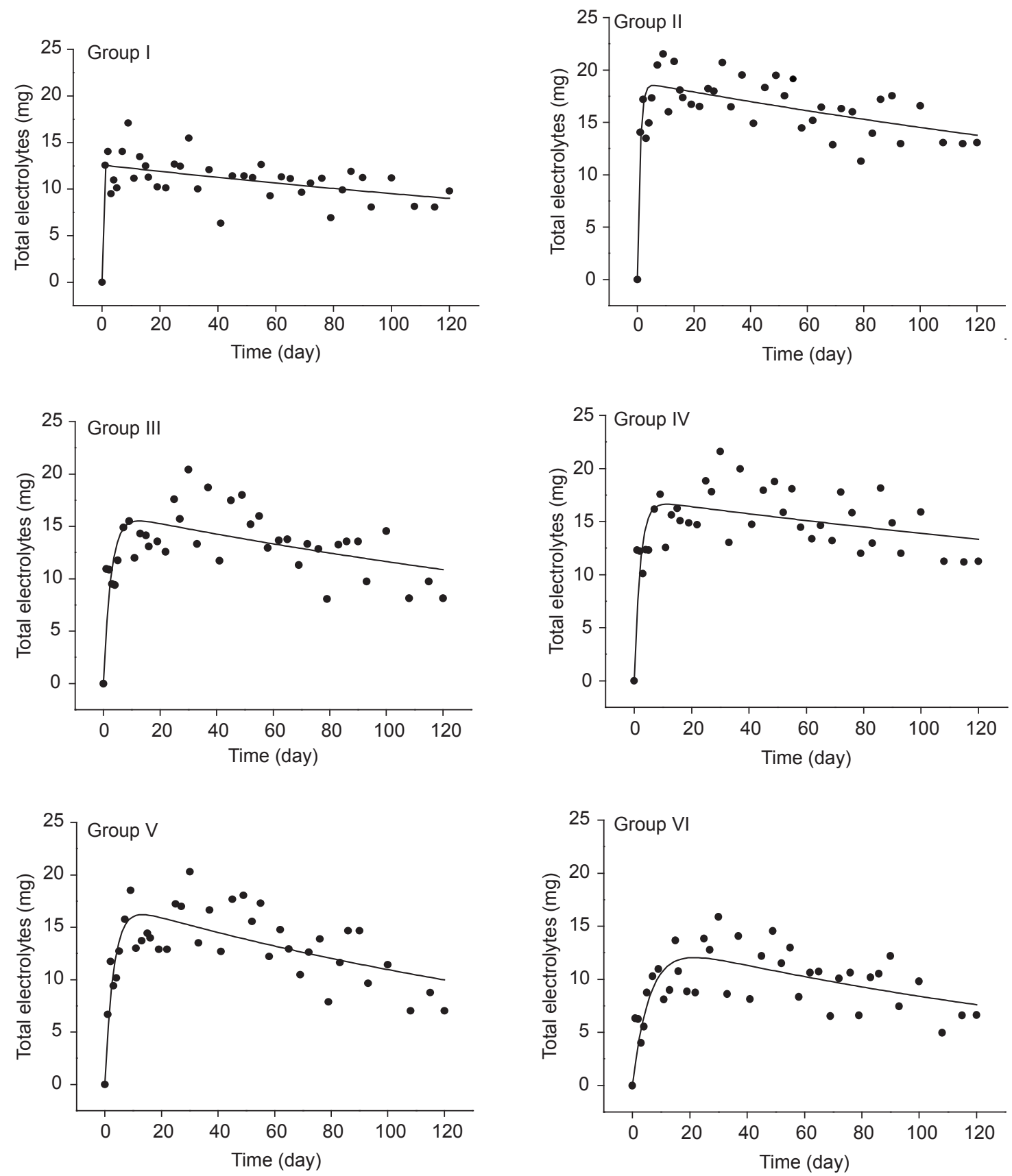

Fig. 3 - Changes of the total dissolved electrolytes contents during the decay of Oxycaryum cubense with different particle size.

immobilization prevailed. The kinetics model for electrolytes (parameterization in Table 2) consider them as intermediate compounds, analogously to what has been suggested for DOM (Bianchini Jr. \& Antonio, 2003). The discrepancies between theory and experimental data $\left(\mathrm{r}^{2}: 0.50\right.$ to 0.68$)$ may be attributed to the periodic oxygenation processes to which the bottles were submitted, part of the discrepancies is caused by the rapid liberation and assimilation of electrolytes. Despite the dispersion 
TABLE 2

Parameterization of total electrolytes variation in function of particle size. Where: $A_{0}=$ maximum total electrolytes formation, $k_{1}=$ leachate coeficient $\left(\right.$ day $\left.^{-1}\right)$ and $k_{\mathrm{a}}$ : assimilation coefficient $\left(\right.$ day $\left.^{-1}\right), t_{1 / 2}=\mathrm{TE}$ formation and consumption half-time; $\mathbf{r}^{2}=$ determination coefficient and error $=$ error referred to the kinetics fittings.

\begin{tabular}{|c|c|c|c|c|c|c|c|c|c|}
\hline Group & $\begin{array}{c}\mathbf{A}_{\mathbf{o}} \\
\left(\mathrm{mg}^{-1}\right)\end{array}$ & Error & $\begin{array}{c}\mathbf{k}_{1} \\
\left(\mathbf{d a y}^{-1}\right)\end{array}$ & Error & $\begin{array}{c}\mathbf{t}_{1 / 2} \\
\text { (day) }\end{array}$ & $\begin{array}{c}\mathbf{k}_{\mathrm{a}} \\
\left(\mathbf{d a y}^{-1}\right)\end{array}$ & Error & $\begin{array}{r}t_{1 / 2} \\
\text { (day) }\end{array}$ & $\mathbf{r}^{2}$ \\
\hline I & 12.59 & 0.54 & 3.66 & 0.00 & 0.2 & 0.0028 & 0.0008 & 247.6 & 0.55 \\
\hline II & 18.81 & 0.67 & 1.06 & 0.28 & 0.7 & 0.0026 & 0.0006 & 266.6 & 0.68 \\
\hline III & 16.20 & 1.01 & 0.38 & 0.10 & 1.8 & 0.0034 & 0.0011 & 203.9 & 0.50 \\
\hline IV & 17.03 & 0.92 & 0.48 & 0.12 & 1.4 & 0.0021 & 0.0009 & 330.1 & 0.53 \\
\hline V & 17.24 & 1.04 & 0.33 & 0.08 & 2.1 & 0.0047 & 0.0015 & 147.5 & 0.60 \\
\hline VI & 13.41 & 1.22 & 0.17 & 0.05 & 4.1 & 0.0050 & 0.0016 & 138.6 & 0.52 \\
\hline
\end{tabular}

of experimental results, its amplitude appears to decrease with increasing initial size of the detritus particles.

The availability of inorganic elements $\left(\mathrm{A}_{0}\right)$ and their coefficient of solubilization and assimilation depend on the size of the detritus (Fig. 3 and Table 2). The changes, however, are very small if one considers the variation in the initial size of the fragments. For the ratio between maximum and minimum values for the quantity of electrolytes, leaching and assimilation coefficients are respectively $1.5,22.2$ and 2.4. From the fitting of the electrolyte kinetics, it is possible to observe that the mechanical fragmentation caused the quantity of electrolytes available to microorganisms to increase and their leaching rates to decrease. With the exception of the Group IV (mean size $=0.78 \mathrm{~mm}$ ) detritus, the decrease in size led to higher electrolyte assimilation coefficients which probably indicates a stronger microbial action in the media comprising smaller detritus. Three main reasons may be identified for explaining the decrease in the liberation of inorganic compounds with decreasing detritus size: i) increase in specific surface area containing free radicals; ii) increase in the assimilation activity of microorganisms; and iii) formation of humic compounds in the particulate matter which contain electrolytes and chelation between the humic compounds and the inorganic elements.

The temporal variation of consumption of DO is shown in Fig. 4 for different initial detritus particle sizes. These results were fitted using a kinetics model (Equations 1 and 2). Exponential equations are frequently used in the description of degradation and mineralization processes of terrestrial as well as aquatic ecosystems (Borsuk \& Stow, 2000). Although mathematical models that assume the heterogeneity of organic matter in the detritus which employed distinct parameters for describing various constituents of substrate (Mindermann, 1968) have been used, much work has adopted simple exponential models to describe the aerobic mineralization of detritus (Lemos \& Bianchini Jr, 1998; Brum et al., 1999; Farjalla et al., 1999; Bitar \& Bianchini Jr., 2002). Up to the $20^{\text {th }}$ day the accumulated consumption was practically the same for all chambers. This was to be expected since at this stage of mineralization, the compounds responsible for DO consumption probably originate from protoplasmatic fractions leaching. These fractions are extremely labile as they are composed mainly of carbohydrates, polyphenols and glycosides (Bianchini Jr. et al., 1984; Cunha \& Bianchini Jr., 1998).

Another important observation related to the small differences is the DO consumption, even though there are significant changes in the initial size of the detritus (the Kruskal-Wallis test does dot assigned differences among different detritus particle sizes, $p=0.7570$ ). Indeed, for a maximum ratio of 400 in a detritus size, $\mathrm{OC}_{\max }$ and $\mathrm{k}_{\mathrm{d}}$ ratios are only 1.41 and 1.65 , respectively (Table 2 ). However, by matching the experimental results to a kinetic model (Fig. 4 and Table 2), as the detritus size decreased (from Group I to group V), two effects occur: i) an increase in the amount of available organic matter for mineralization and/or the stoichiometry of oxygen and carbon was altered resulting in a higher consumption of oxygen; and ii) the mineralization coefficient decreased, that is, there was a tendency to inhibit the velocity wherby 

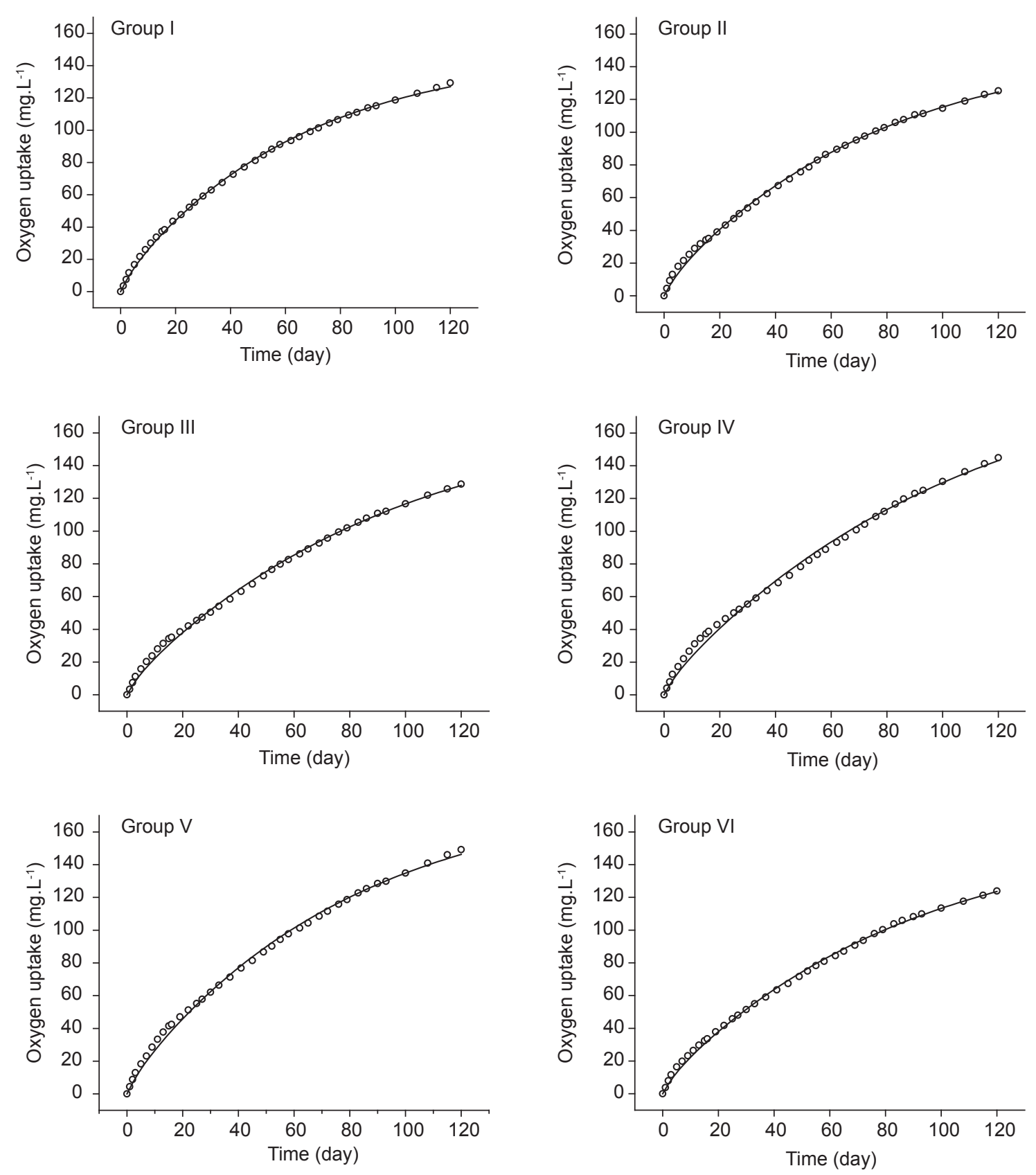

Fig. 4 - Time evolution of oxygen uptake during the mineralization of Oxycaryum cubense with different particle size.

the processes that involved DO consumption occur. This phenomenon probably is referred to by the fact that microorganisms had more access to organic carbon owing to the larger specific surface area of the fragmentized detritus. On the other hand, some exposed carbon is not assimilated or oxidized in a short period (e.g. from lignin and cellulose) that may lead to stoichiometric changes in the oxidative processes and also changes in the total mineralization rates. Such rates may have also been decreased by the formation of refracting compounds (humic and fulvic acids) favored by the reduction in the detritus size. Taking this into account, it is also possible that as the humification 
process is favored, the mineralization of small particles was inhabited (Bianchini Jr. \& Antonio, 2003). Overall, these results suggest that the larger detritus should have a smaller quantity of matter to be mineralized, even though they should possess higher mineralization coefficients due to the type of compounds available.

The mineralization of $O$. cubense presented OC $_{\max }$ varying from 143.2 to $202.6 \mathrm{mg} . \mathrm{g}^{-1}$ DW (Table 3); these values were lower than those observed for mineralization of Cabomba piauhyensis (339.0 mg. ${ }^{-1} \mathrm{DW}$; Cunha \& Bianchini Jr., 1998), Lemna sp. (230.0 mg.g ${ }^{-1}$ DW; Bitar \& Bianchini Jr., 2002), Montrichardia arborescens (235.2 mg.g-1 DW; Cunha-Santino et al., 2004), Nymphaea ampla (258.0 and $450.0 \mathrm{mg} \cdot \mathrm{g}^{-1}$ DW; Brum et al., 1999; Farjalla et al., 1999), Potamogeton stenostachys (360.0 and $377.0{\mathrm{mg} . \mathrm{g}^{-1}}^{-1}$ DW; Brum et al., 1999; Farjalla et al., 1999), Cabomba sp. (342.0 mg.g ${ }^{-1}$ DW; Bitar \& Bianchini Jr., 2002) and Wolffia sp. (573.5 mg.g $\mathrm{g}^{-1}$ DW; Bitar $\&$ Bianchini Jr., 2002). The values obtained in this study for different sizes of detritus are from the same magnitude order to those obtained for this same species in bioassays carried out in the Infernão lagoon (165.3 mg.g ${ }^{-1}$ DW; Cunha \& Bianchini Jr., 1998; Lemos \& Bianchini Jr., 1998). Other species also showed similar or small values for $\mathrm{OC}_{\max }$ : Salvinia sp. (185.0 mg.g ${ }^{-1}$ DW; Bitar \& Bianchini Jr., 2002), Eichhornia azurea (140.0 mg.g ${ }^{-1} \mathrm{DW}$; Bitar \& Bianchini Jr., 2002) and Typha domingensis (32.5 mg. $\mathrm{g}^{-1}$ DW; Farjalla et al., 1999).

The physical process of fragmentation of $O$. cubense detritus is unlikely to promote the consumption of higher quantities of dissolved oxygen in the mineralization process and this conclusion may be possibly extrapolated to other aquatic plants. Moreover, fragmentation should not interfere in the balance of DO in the Infernão lagoon. On the other hand, it appears to affect the availability of inorganic compounds to be released as well as their leaching rates and it favored the acidification. Such results could be significantly altered if interference from herbivorous and detritivorous organisms occurred as fragmentation together with catabolic alterations would accelerate the mineralization processes (Simon \& Benfield, 2001; Mermillod-Blondin et al., 2003). Taking this into account, practically no insects in the sediment have been observed in the Infernão lagoon (Strixino et al., 1997). These organisms are basically found in the biomass of $O$. cubense detritus owing to low concentration of dissolved oxygen at depths $>1.5 \mathrm{~m}$ (Nogueira, 1989; Feresin, 1991; 1994; Gianotti, 1994). This indicates that in this lagoon the decomposition of $O$. cubense is mainly procesed by anaerobic microbial communities.

Acknowledgments - The authors would like to thank Fundação de Amparo à Pesquisa do Estado de São Paulo (FAPESP) for financing this assay (Process no 91/1303-3) and Dr. Osvaldo N. Oliveira Jr. (IFSC-USP) for proofreading the manuscript.

\section{REFERENCES}

ALLAN, J. D., 1995, Stream Ecology - Structure and function of running waters. Chapman \& Hall, London, 388p.

BIANCHINI Jr., I., TOLEDO, A. P. P. \& TOLEDO, S. H. P. P., 1984, Influência do tempo na variedade e quantidade de polifenóis dissolvidos, originados da decomposição de plantas aquáticas. An. Sem. Reg. Ecol. IV, São Carlos, SP, pp. 167-181.

TABLE 3

Parameterization of oxygen uptake in function of particle size. Where: $\mathrm{OC}_{\max }=$ maximum oxygen consumption; $k_{d}=$ DO consumption coefficient; $t_{1 / 2}=$ DO consumption half-time; $r^{2}=$ determination coefficient and error $=$ error referred to the kinetics fittings.

\begin{tabular}{|c|c|c|c|c|c|c|}
\hline Group & $\begin{array}{c}\mathbf{O C}_{\text {max }} \\
\left(\mathbf{m g . g}^{-1}\right)\end{array}$ & Error & $\begin{array}{c}\mathbf{k}_{\mathbf{d}} \\
\left(\mathbf{d a y}^{-1}\right)\end{array}$ & Error & $\begin{array}{c}\mathbf{t}_{\mathbf{1} / \mathbf{2}} \\
\left(\mathbf{d a y}^{\mathbf{1}}\right)\end{array}$ & $\mathbf{r}^{\mathbf{2}}$ \\
\hline I & 143.2 & 1.47 & 0.0156 & 0.0003 & 44.35 & 0.99 \\
\hline II & 148.7 & 2.80 & 0.0132 & 0.0004 & 52.42 & 0.99 \\
\hline III & 171.0 & 4.80 & 0.0104 & 0.0004 & 66.53 & 0.99 \\
\hline IV & 202.6 & 8.30 & 0.0094 & 0.0006 & 73.61 & 0.99 \\
\hline V & 180.5 & 4.31 & 0.0125 & 0.0005 & 55.36 & 0.99 \\
\hline VI & 157.9 & 3.37 & 0.0114 & 0.0004 & 60.71 & 0.99 \\
\hline
\end{tabular}


BIANCHINI Jr., I., \& TOLEDO, A. P. P., 1988, Decomposição de macrófitas aquáticas: Estudo da variação do $\mathrm{pH}$ e densidade óptica em ensaios sob diferentes condições de atmosfera e luminosidade. An. Sem. Reg. Ecol. V, São Carlos, SP, pp. 167- 181.

BIANCHINI Jr., I. \& ANTONIO, R. M., 2003, The effect of particle size on the leaching of Scirpus cubensis Poepp \& Kunth. Braz. J. Biol., 63(2): 195-205.

BITAR, A. L. \& BIANCHINI Jr., I., 2002, Mineralisation assays of some organic resources of aquatic systems. Brazil. J. Biol., 62(4A): 557-564.

BORSUK, M. E. \& STOW, C. A., 2000, Bayesian parameter estimation in a mixed-order model of BOD decay. Water Res., 34(6): 1830-1836.

BRUM, P. R., FARJALLA, V. F., GONÇALVES Jr., J. F., SANTOS, A. M., PÔRTO, M. T., VIEIRA, E. D. R., FERREIRA, F. M. \& BIANCHINI Jr,. I., 1999, Aspects of the uptake of dissolved oxygen in Cabiúnas and Imboassica Lagoons (Macaé, RJ). Brazil. Archiv. Biol. Technol., 42(4): 433-440.

CUNHA, M. B. \& BIANCHINI Jr., I., 1998, Mineralização aeróbia de Cabomba piauhyensis e Scirpus cubensis. Acta Limnol. Brasil., 10(1): 81-91.

CUNHA-SANTINO, M. B. \& BIANCHINI JÚNIOR, I., 2002, Estequiometria da decomposição aeróbia de galhos, cascas serapilheira e folhas, pp. 43-56. In: E. L. G. Espíndola, F. F. Mauad, W. Schalch, O. Rocha, N. Felicidade \& A. C. Rietzler, (Ed.). Recursos hidroenergéticos: usos, impactos e planejamento integrado. RiMa, São Carlos.

CUNHA-SANTINO, M. B. \& BIANCHINI Jr., I., 2002, Humic substance mineralisation from a tropical oxbow lake (São Paulo, Brazil). Hydrobiologia, 236: 34-44.

CUNHA-SANTINO, M. B. \& BIANCHINI Jr., I., 2003, Determination of the aeration coefficient for long-term BOD experiments. Acta Scientiarum, 25(2): 253-256.

CUNHA-SANTINO, M. B. \& BIANCHINI Jr., I., 2004, Humic substances mineralization: the variation of $\mathrm{pH}$, electrical conductivity and optical density. Acta Limnol. Brasil., 16(1): 63-75.

CUNHA-SANTINO, M. B., PACOBAHYBA, L. D. \& BIANCHINI JÚNIOR, I., 2004, Oxygen uptake from mineralization of Montrichardia arborescens. Acta Limnol. Brasil., 16(4): 351-357.

FARJALLA, V. F., MARINHO, C. C. \& ESTEVES, F. A., 1999, Uptake of oxygen in the initial stages of decomposition of aquatic macrophytes and detritus from terrestrial vegetation in a tropical coastal lagoon. Acta Limnol. Brasil., 11(2): 185-193.

FERESIN, E. G., 1991, Nitrificação em uma lagoa marginal do rio Mogi Guaçu (Lagoa do Infernão, Estação Ecológica de Jataí - Luiz Antonio, SP). Dissertação de Mestrado - Universidade Federal de São Carlos, São Carlos, 69p.

FERESIN, E. G., 1994, Produção de Carbono Orgânico via Fitoplâncton e Bacterioplâncton em Duas Lagoas da Planície de Inundação do Rio Mogi Guaçu (Estação Ecológica de Jataí, SP). Tese de Doutorado - Universidade Federal de São Carlos, São Carlos, 108p.

GIANOTTI, E. P., 1994, Desnitrificação em uma Lagoa Marginal do Rio Mogi Guaçu, Lagoa do Infernão (Estação
Ecológica de Jataí - Município de Luíz Antônio - SP). Tese de Doutorado - Universidade Federal de São Carlos, São Carlos, 298p.

GUPTA, M. K., SHRIVASTAVA, P. \& SINGHAL, P. K., 1996, Decomposition of young water hyacinth leaves in lake water. Hydrobiologia, 335: 33-41.

HENZE, M., HARREMOËS, P., JANSEN, J. C. \& ARVIN, E., 2001, Wastewater Treatment- Biological and chemical processes. Springer-Verlag, Berlin, 430p.

HOEHNE, F. C., 1979, Plantas Aquáticas. Instituto de Botânica, São Paulo, 168p.

JOLY, A. B., 1977, Botânica: Introdução à Taxonomia Vegetal. Companhia Editora Nacional, São Paulo, 775p.

LEMOS, R. M. A. \& BIANCHINI Jr., I., 1998, Decomposição de Scirpus cubensis Poepp \& Kunth da lagoa do Infernão (SP): I Efeito do teor de nitrogênio e da quantidade de matéria orgânica. An. Sem. Reg. Ecol. VIII, São Carlos, SP, pp. 1271-1287.

LU, X. Q., HANNA, J. V. \& JOHNSON, W. D., 2001, Evidence of chemical pathways of humification: a study of aquatic humic substances heated at various temperatures. Chem. Geol., 177: 249-264.

MACKENSEN, J. \& BAUHUS, J., 1999, The decay of course wood debris. National Carbon Accountin Systems, (Report n. 6). Australian Greenhouse Office, Australia, 41p.

MERMILLOD-BLONDIN. F., GAUDET, J. P., GERINO, M., DESROSIERS, G. \& CHATELLIERS, M. C., 2003, Influence of macroinvertebrates on physico-chemical and microbial processes in hyporheic sediments. Hydrological Processes, 17(4): 779-794.

MINDERMANN, G., 1968, Addition, decomposition and accumulation of organic matter in forests. J. Ecol., 56: 355-562.

MUN, H. T., NAMGUNG, J. \& KIM, J. H., 2001, Decay rate and changes of nutrients during decomposition of Zizania latifolia. Korean Journal of Ecology, 24(2): 81-85.

NOGUEIRA, F., ESTEVES, F. A. \& PRAST, A. E., 1996, Nitrogen and phosphorus concentration of different structures of the aquatic macrophytes Eichhornia azurea Kunth and Scirpus cubesis Poepp \& Kunth in relation to water level variation in Lagoa do Infernão (São Paulo, Brazil). Hydrobiologia, 328: 199-205.

NOGUEIRA, F. M. B., 1989, Importância das macrófitas aquáticas Eichhornia azurea Kunth e Scirpus cubensis Poepp \& Kunth na ciclagem de nutrientes e nas principais características limnológicas da Lagoa Infernão (SP). Dissertação de Mestrado - Universidade Federal de São Carlos, São Carlos, 147p.

PANHOTA, R. S. \& BIANCHINI Jr., I., 2003, Potential cycling of organic matter in a eutrophic reservoir (Barra Bonita - SP - Brazil). Acta Limnol. Brasil., 15(2): 1-11.

SIMON, K. S. \& BENFIELD, E. F., 2001, Leaf and wood breakdown in cave streams. J. NorthAmerican Benthological Society, 20(4): 550-563.

STRIXINO, G., TRIVINHO-STRIXINO, S. \& ALVES, G. R., 1997, Macroinvertebrados benttônicos de lagoas marginais da planície de inundação do rio Mogi-Guaçu (Estação Ecológica de Jataí). An. Sem. Reg. Ecol., 8: 33-42. São Carlos, SP. 